\title{
TAHAP DAN PENENTU INDEKS MODAL SOSIAL DI MALAYSIA
} LEVEL AND DETERMINANTS OF SOCIAL CAPITAL INDEX IN MALAYSIA

\section{Rahmah Ismail*, Noor Dzaharah Mahfodz and Noorasiah Sulaiman}

School of Economics, Faculty of Economics and Management, Universiti Kebangsaan Malaysia, MALAYSIA

*Corresponding author: rahis@ukm.edu.my

To cite this article: Rahmah Ismail, Noor Dzaharah Mahfodz and Noorasiah Sulaiman. 2016. Tahap dan penentu indeks modal sosial di Malaysia. Kajian Malaysia 34(2): 101-121. http://dx.doi.org/10.21315/km2016.34.2.5

To link to this article: http://dx.doi.org/10.21315/km2016.34.2.5

\begin{abstract}
ABSTRAK
Modal sosial merupakan salah satu elemen penting dalam mengurangkan insiden kemiskinan kerana ia mampu mempengaruhi tingkat pendapatan individu atau isi rumah dalam sesebuah negara. Namun, kajian lepas yang melihat isu modal sosial masih kurang terutamanya di Malaysia. Kajian ini bertujuan untuk menentukan tahap dan mengenal pasti penentu indeks modal sosial di Malaysia berdasarkan data 2,443 orang ketua isi rumah yang telah dikutip pada tahun 2012 di lima buah negeri di Semenanjung Malaysia; iaitu Kedah, Selangor, Wilayah Persekutuan Kuala Lumpur, Johor dan Terengganu. Analisis kajian ini melibatkan dua peringkat; iaitu menghitung indeks modal sosial dan menganggar model regresi untuk mengenal pasti penentu indeks modal sosial. Dapatan kajian ini menunjukkan $72.9 \%$ ketua isi rumah berada pada tahap indeks modal sosial peringkat sederhana dan tinggi, iaitu 0.5 dan ke atas. Peratus ketua isi rumah di negeri Selangor yang berada pada tahap indeks modal sosial yang tinggi adalah lebih tinggi dibandingkan dengan di negerinegeri lain. Selanjutnya dapatan kajian menunjukkan penentu indeks modal sosial yang signifikan adalah status perkahwinan, lokasi, negeri dan pendapatan isi rumah. Dapatan kajian ini memberi implikasi bahawa Malaysia perlu menjalankan program yang dapat meningkatkan pendapatan individu atau isi rumah demi meningkatkan indeks modal sosial mereka yang selanjutnya meningkatkan tahap pembangunan ekonomi Malaysia.
\end{abstract}

Kata kunci: modal sosial, indeks modal sosial, isi rumah, insiden kemiskinan 


\begin{abstract}
Social capital is one of the important elements to reduce the incidence of poverty because of its ability to influence an individual's or household's income of a country. Nevertheless, past studies that examine social capital issue are rather lacking especially in Malaysia. This study aims to identify the level and determinants of social capital index in Malaysia based on 2,443 heads of households' data collected in 2012 in five states in Peninsular Malaysia; Kedah, Selangor, Federal Territory of Kuala Lumpur, Johor and Terengganu. The analysis involves two steps; computing social capital index and estimating regression models to identify the determinants of social capital index. The study finds that $72.9 \%$ of heads of households are having moderate and high social capital index of 0.5 and above. The percentage of heads of households with higher social capital index is higher in Selangor compared to other states. Further, the study demonstrates that the significant determinants of social capital index are marital status, location, states, and household income. The findings from the study imply that Malaysia must implement programmes that can raise an individual's or household's income in order to increase their level of social capital index, which subsequently will improve Malaysia's level of economic development.
\end{abstract}

Keywords: social capital, social capital index, household, incidence of poverty

\title{
PENGENALAN
}

Modal sosial didefinisikan sebagai ciri-ciri sosial seperti jaringan sosial (social networking), kebolehpercayaan (trustworthy) dan norma hidup (norms) yang mampu menghasilkan eksternaliti positif dan memperbaiki kecekapan individu atau masyarakat (Coleman, 1988; 1990; Putnam, 1993; Fukuyama, 1999). Jaringan sosial merangkumi penglibatan dan hubungan individu dalam persatuan, kelab atau organisasi tertentu. Kebolehpercayaan pula merupakan hubungan antara keluarga, saudara mara, rakan dan kenalan, budaya dan agama. Sementara norma hidup meliputi amalan, budaya dan cara kehidupan umum yang diperlihatkan oleh sesebuah komuniti atau bangsa (Seligman, 1997).

Modal sosial telah pun dibincangkan secara meluas dalam kajian-kajian lepas dan telah memberi kesan positif terhadap ekonomi dan pembangunan sosial (Roslan, Russayani dan Nor Azam, 2010). Malah modal sosial merupakan salah satu faktor yang dapat menerangkan perbezaan tingkat pembangunan mengikut wilayah dan komuniti. Knack (2002) menyatakan bahawa modal sosial mampu mempengaruhi kemampuan individu untuk bekerjasama bagi mencapai sesuatu matlamat. 
Putnam (2001) menghujah bahawa kebajikan sesebuah masyarakat dapat diperbaiki menerusi peningkatan modal sosial. Pihak kerajaan dikatakan berjaya dalam membangunkan modal sosial sekiranya berupaya melaksanakan amalan pentadbiran yang baik. Hal ini disebabkan pentadbiran yang mendapat mandat atau kepercayaan rakyat berupaya menyumbang kepada peningkatan prestasi ekonomi melalui peningkatan akses atau peluang dalam kalangan penduduk. Antaranya menyediakan akses dan kemudahan kepada golongan berpendapatan sederhana dan rendah dengan pelbagai peluang ekonomi yang dapat menjana pendapatan. Hal ini seterusnya dapat memperbaiki corak agihan pendapatan dan mengurangkan kadar kemiskinan dalam sesebuah negara.

Kepentingan modal sosial selaras dengan matlamat pembangunan ekonomi Malaysia yang menjurus kepada mengurangkan jurang perbezaan ekonomi dan pendapatan antara kawasan bandar dan luar bandar serta antara etnik. Secara umumnya, matlamat ini boleh dibantu oleh tiga komponen modal utama; iaitu modal sosial, modal manusia, dan modal fizikal. Namun mutakhir ini peranan modal sosial lebih diketengahkan. Usaha ke arah meningkatkan modal sosial adalah bertunjangkan kepada pembangunan modal sosial yang mantap akan dapat meningkatkan mobilisasi sumber sesebuah komuniti serta mempertingkatkan semangat perpaduan dalam kalangan rakyat. Ia sekaligus dapat menjayakan Program Transformasi Ekonomi yang memerlukan penglibatan menyeluruh rakyat negara ini. Tambahan pula pembangunan modal sosial yang mantap mampu menjadikan masyarakat lebih berdaya saing, dinamik, proaktif dan memiliki daya tahan yang tinggi ketika berlakunya sebarang krisis sama ada krisis politik mahupun krisis ekonomi (Jabatan Perdana Menteri, 2014).

Pengaruh modal sosial dalam masyarakat alaf baru adalah berasaskan struktur jaringan dan kebolehpercayaan dalam kalangan masyarakat. Hal ini sejajar dengan intipati Dasar Sosial Negara yang menekankan konsep saling bekerjasama dan bersatu padu serta hubungan baik yang terjalin antara individu dalam sesebuah komuniti atau masyarakat. Penekanan dalam nilai dan norma hidup penting supaya jaringan sosial dapat dibentuk, diperkukuh dan diserap dalam setiap diri manusia (Jabatan Kebajikan Masyarakat, 2003). Perkara ini dibuktikan melalui kajian Noorasiah dan Mohd Nasir (2007) dengan menggunakan data pengusaha Melayu sektor pembuatan di Semenanjung Malaysia yang menunjukkan bahawa modal sosial mempunyai pengaruh penting terhadap tingkat daya saing sesebuah firma. Tingkat modal sosial memainkan peranan dalam meningkatkan jaringan sama ada secara formal mahupun tidak formal yang merangkumi hubungan dalam sektor, hubungan antara sektor dan hubungan dengan masyarakat.

Namun kajian yang melihat kepada isu dan kepentingan modal sosial di Malaysia masih kurang. Apatah lagi kajian yang membincangkan kaedah pengukurannya dan faktor yang menentukan tingkat modal sosial individu. Jadi persoalannya adalah apakah tahap modal sosial dalam kalangan rakyat Malaysia dan sejauh manakah ciri individu mempengaruhi tahap ini? Kebanyakan kajian di 
Malaysia adalah terhad kepada takrif modal sosial atau mengkaji pengaruh modal sosial terhadap daya saing (Noorasiah dan Mohd Nasir, 2007; Bjørnskov dan Svendsen 2003; Grootaert, 2004). Setakat ini tidak terdapat kajian di Malaysia yang membentuk indeks modal sosial dan mengenal pasti penentu indeks ini. Pengukuran modal sosial melalui pembentukan indeks adalah lebih baik dibandingkan dengan pengukurannya secara terpisah memandangkan indeks ini dibentuk berasaskan kepada gabungan pelbagai indikator. Hal ini menjadikan konsep indeks modal sosial adalah lebih komprehensif dan kukuh yang amat diperlukan sebagai asas kepada implikasi dasar.

Artikel ini bertujuan untuk membentuk indeks modal sosial dalam kalangan ketua isi rumah di Malaysia dan menganalisis faktor penentu indeks modal sosial. Analisis kajian ini menggunakan data sebanyak 2,443 orang ketua isi rumah yang telah dikutip pada tahun 2012 di lima buah negeri di Semenanjung Malaysia, iaitu Kedah, Selangor, Wilayah Persekutuan Kuala Lumpur, Johor dan Terengganu. Penulisan artikel ini dibahagikan kepada lima bahagian. Bahagian berikutnya membincangkan kajian lepas diikuti dengan data dan metodologi, keputusan kajian dan kesimpulan pada bahagian akhir.

\section{KAJIAN LEPAS}

Terdapat pelbagai pengukuran modal sosial dan setiap pengukuran yang berbeza ini boleh memberi hasil yang berbeza dalam setiap kajian yang dijalankan. Putnam (1993) telah memperkenalkan satu ukuran mudah modal sosial dalam menganalisis perbezaan kecekapan institusi dan pengaruhnya dalam pembangunan ekonomi antara Itali Utara dengan Itali Selatan. Ukuran modal sosial yang digunakan ialah jumlah organisasi sukarela yang wujud dalam sesebuah institusi. Bjørnskov dan Svendsen (2003) menggunakan cara pengukuran yang lebih baik dengan memasukkan lebih banyak indikator modal sosial. Komponen modal sosial dalam kajian mereka terdiri daripada organisasi dalam komuniti, keahlian dalam persatuan, kepercayaan sosial, kerja sukarela dalam komuniti, rasuah dan kebebasan. Dalam melihat kepentingan indikatorindikator ini, mereka mengadaptasikan analisis komponen faktor.

Krishna dan Uphoff (1999) telah membina indeks modal sosial berdasarkan dua pengertian, iaitu modal sosial struktur yang terdiri daripada tiga indikator, iaitu jaringan, berpersatuan, dan institusi serta modal sosial kognitif yang terdiri daripada indikator modal sosial yang lebih bersifat subjektif, iaitu sikap, norma hidup dan nilai serta kebolehpercayaan. Indeks ini didapati mempunyai hubungan yang positif dan signifikan dengan indeks pembangunan ekonomi. Narayan dan Michael (2001) juga telah menggunakan metodologi yang sama bagi kajian mereka di Afrika Barat.

Di peringkat makro, modal sosial memberi pengaruh yang kuat kepada pertumbuhan ekonomi yang dianggap sama penting dengan pengaruh modal 
manusia (Whiteley, 2000). Dalam konteks yang lebih luas, kerajaan yang mengamalkan pentadbiran yang baik dan telus berupaya meningkatkan modal sosial menerusi peningkatan dalam akses penduduk terhadap peluang-peluang dalam ekonomi yang akhirnya memperbaiki agihan pendapatan dan mengurangkan kadar kemiskinan (Knack, 2002). Peningkatan dalam modal sosial juga membantu dalam meningkatkan pendapatan isi rumah dan mengurangkan perbezaan pendapatan dalam kalangan mereka (Robinson, 1999).

Boxman, De Graaf dan Flap (1991) mendapati modal sosial memberi kesan positif kepada tingkat pendapatan pekerja peringkat pengurusan di Belanda. Kajian ke atas 26 negara-negara Eropah pula telah membuktikan bahawa modal sosial mempunyai hubungan yang positif dengan tingkat pendapatan individu tanpa mengira pekerjaan (Hermann dan Mahieu, 2012). Apa yang menarik daripada kajian tersebut adalah modal sosial dan modal manusia boleh bertindak sebagai pengganti antara satu sama lain. Selain itu, modal sosial berupaya meningkatkan pendapatan individu walaupun mereka mempunyai tahap pendidikan yang berbeza.

Penglibatan individu dalam organisasi merupakan salah satu ukuran modal sosial. Menurut Katungi, Machethe dan Smale (2007) antara faktor yang mempengaruhi isi rumah untuk melibatkan diri dalam sesebuah organisasi tempatan ialah ciri-ciri mereka termasuk umur, jantina, kekayaan isi rumah, pendidikan, status sosial, nisbah pengguna kepada pekerja dan akses kepada kemudahan berkomunikasi atau bersosial. Menurut pengkaji-pengkaji ini, isi rumah yang mempunyai nisbah pengguna kepada pekerja yang lebih tinggi akan terdedah kepada risiko kematian dan kebuluran dan risiko tersebut akan menyebabkan mereka semakin bergantung kepada orang lain.

Kajian di atas juga mendapati kaum wanita di kawasan pedalaman Afrika mempunyai kekangan masa yang lebih tinggi berbanding kaum lelaki kerana mereka terpaksa melakukan kerja rumah. Begitu juga norma-norma negatif terhadap wanita yang diterapkan dalam masyarakat mereka menyebabkan wujud kekangan dalam interakasi sosial antara kaum wanita di pedalaman Afrika. Menurut Maluccio, Haddad dan May (2003), isi rumah wanita juga tidak dapat melibatkan diri dalam organisasi yang mengenakan yuran keahlian disebabkan kekangan kewangan. Glaeser, Laibson dan Sacerdote (2002) pula menyatakan bahawa individu yang melabur dalam modal manusia dan modal fizikal akan cenderung untuk melabur dalam modal sosial. Begitu juga isi rumah yang berkemampuan atau kaya akan lebih terlibat dalam organisasi sosial untuk mendapatkan pengaruh sosial berbanding golongan kurang mampu atau miskin.

Kajian Kaasa dan Parts (2008) melihat pelbagai penentu modal sosial individu di negara Eropah. Mereka memasukkan faktor demografi seperti umur, jantina, status perkahwinan dan bilangan anak sebagai penentu modal sosial. Mereka mendapati umur merupakan penentu penting modal sosial, terutamanya terhadap kepercayaan dan jaringan secara rasmi. Mereka juga menemui bahawa penglibatan kaum wanita dalam jaringan sosial adalah lebih rendah berbanding 
kaum lelaki. Kajian Christoforou (2005) pula mendapati perkahwinan telah meningkatkan kebarangkalian untuk pasangan tersebut melibatkan diri dalam aktiviti berkumpulan. Begitu juga penglibatan kaum lelaki yang sudah berkahwin dalam jaringan sosial adalah lebih tinggi berbanding kaum wanita yang sudah berkahwin. Knack dan Keefer (1997) pula menunjukkan tingkat pendapatan dan pendidikan yang tinggi meningkatkan kepercayaan interpersonal dan keahlian dalam kumpulan. Malah individu yang lebih berpendidikan lebih senang untuk dipercayai berbanding mereka yang kurang berpendidikan.

Menurut Kaasa dan Parts (2008), saiz isi rumah yang merujuk kepada bilangan anak memberi kesan yang negatif dan signifikan kepada setiap jenis jaringan sosial. Fidrmuc dan Gerxhani (2004) pula telah menunjukkan bahawa individu yang tinggal di kawasan bandar yang bersaiz sederhana kurang melibatkan diri dalam organisasi rasmi dan tidak rasmi. Sementara dapatan Alesina dan La Ferrara (2000) menunjukkan individu kurang bersosial di kawasan bandar yang besar. Glaeser, Laibson dan Sacerdote (2002) mendapati seorang pemilik rumah akan meningkatkan modal sosial kerana terpaksa terlibat dalam banyak urusan dengan individu lain.

Christoforou (2005) telah menganggar satu model regresi dengan menggunakan data individu di Greece dan Kesatuan Eropah yang terdiri daripada 15 buah negera. Dalam kajian ini, beliau membahagikan penentu modal sosial kepada dua kumpulan, iaitu penentu di peringkat individu dan penentu di peringkat agregat. Penentu di peringkat individu termasuklah pendapatan individu, tingkat pendidikan, status pekerjaan, umur, jantina dan status perkahwinan. Sementara penentu di peringkat agregat pula termasuklah dami bagi negera atau wilayah dan beberapa pemboleh ubah sosioekonomi seperti Keluaran Dalam Negara Kasar (KDNK), pengangguran dan ketidakseimbangan agihan pendapatan. Dapatan kajian ini menunjukkan penentu di peringkat individu lebih dominan dalam mempengaruhi modal sosial.

\section{METODOLOGI}

\section{Sumber Data}

Kajian ini menggunakan satu set data primer yang dikutip melalui kerja lapangan dengan menggunakan borang soal selidik pada tahun 2012. Kajian ini mengkategorikan negeri-negeri di Malaysia berasaskan Indeks Kemajuan Komposit yang mengandungi Indeks Pembangunan Ekonomi dan Indeks Pembangunan Sosial (Unit Perancang Ekonomi, 2006) dan memilih hanya lima negeri untuk mewakili negeri maju dan kurang maju. Negeri maju diwakili oleh Selangor, Wilayah Persekutuan Kuala Lumpur dan Johor, manakala Kedah dan Terengganu mewakili negeri kurang maju. Selanjutnya bagi setiap negeri, pemilihan sampel dibuat mengikut strata iaitu, bandar dan luar bandar. Pemilihan 
sampel bagi kajian ini dilakukan melalui teknik persampelan berstrata duaperingkat, dengan peringkat pertama berasaskan negeri dan peringkat kedua berasaskan bandar dan luar bandar.

Sampel kajian ini terdiri daripada ketua isi rumah lelaki dan wanita. Penentuan sampel minimum adalah berasaskan kepada kaedah pembahagian yang diperkenalkan oleh Israel (1992). Sejumlah 3,000 borang soal selidik telah diagihkan kepada isi rumah dan daripada jumlah tersebut 1,700 sampel mewakili negeri maju, manakala 1,300 sampel mewakili negeri kurang maju. Bagi negeri maju, 900 adalah terdiri daripada isi rumah di kawasan bandar dan 800 isi rumah di kawasan luar bandar. Sementara bagi negeri kurang maju, 750 adalah isi rumah di kawasan bandar dan 550 isi rumah di kawasan luar bandar. Daripada jumlah ini hanya 2,600 borang soal selidik telah berjaya dikutip dan terdapat hanya 2,443 (94\%) borang soal selidik yang lengkap dan boleh digunakan dalam analisis artikel ini.

Borang soal selidik terdiri daripada tiga bahagian; iaitu Bahagian A, B dan C. Bahagian A mengandungi soalan tentang profil responden, manakala Bahagian B merupakan soalan mengenai pendapatan dan perbelanjaan responden. Bahagian $\mathrm{C}$ pula mengandungi soalan berkaitan modal sosial yang terdiri daripada tiga indikator; iaitu hubungan dan jaringan, kebolehpercayaan, norma hidup dan budaya. Pembentukan borang soal selidik adalah berasaskan kepada World Bank Integrated Social Capital Survey (Grootaert, 2004). Setiap indikator modal sosial yang mengandungi beberapa item akan dijawab oleh responden dengan menggunakan skala Likert antara 1 hingga 5 (Skala 1 adalah tidak bersetuju dan Skala 5 adalah sangat bersetuju). Aspek hubungan dan jaringan terdiri daripada 12 item, iaitu yang berkaitan dengan penyertaan dalam persatuan, kekerapan mengambil bahagian dalam aktiviti persatuan, bilangan rakan rapat dan bagaimana responden berinteraksi dengan rakan. Aspek kebolehpercayaan mempunyai 10 item yang terdiri daripada perkara yang berkaitan dengan bantuan kewangan dan bukan kewangan. Dari segi kebolehpercayaan kewangan, itemnya individu yang boleh dipercayai apabila menghadapi masalah kewangan, manakala kebolehpercayaan bukan kewangan termasuklah individu yang boleh membantu apabila menghadapi kecemasan. Aspek norma hidup dan budaya pula mempunyai enam item yang terdiri daripada hubungan dengan rakan dan perkongsian maklumat.

Bagi menguji kebolehpercayaan instrumen, ujian kebolehpercayaan (reliability test) dilakukan. Nilai Cronbach's Alpha bagi indikator-indikator modal sosial kajian ini ialah 0.798 bagi hubungan dan jaringan sosial, 0.761 bagi kebolehpercayaan dan 0.879 bagi norma hidup dan budaya. Kesemua nilai ini melepasi nilai minimum (0.7) untuk Cronbach's Alpha (Hair, 2010) dan keputusan ini mengesahkan bahawa kesemua item dalam setiap indikator modal sosial mempunyai kolerasi yang tinggi. 


\section{Pengiraan Indeks Modal Sosial}

Proses mendapatkan indeks modal sosial dilakukan dengan menggunakan formula di bawah yang diadaptasikan daripada kajian Rahmah et al. (2009). Indeks modal sosial dibentuk dengan menjumlahkan indeks bagi setiap indikator modal sosial; iaitu hubungan dan jaringan, kebolehpercayaan, norma hidup dan budaya. Persamaan umum berikut digunakan untuk mendapatkan indeks bagi setiap indikator.

$$
I_{i j}=\frac{1}{l_{k}} \sum \tilde{X}_{i j k}
$$

Dengan $I_{i j}$ merupakan indeks indikator ke- $j$ bagi individu $i$ yang diperolehi secara purata setelah dibahagikan dengan bilangan item $\left(l_{k}\right)$ yang terdapat dalam setiap indikator ke-j. Sementara $X_{i j k}$ pula merupakan penormalan jumlah nilai skor individu $i$ bagi setiap indikator $j$ dan setiap item $k$ yang dikira dengan menggunakan formula berikut:

$$
\tilde{X}_{i j k}=\frac{\text { Nilai sebenar }_{k}-\text { Nilai Minimum }_{k}}{\text { Nilai Maksimum }_{k}-\text { Nilai Minimum }_{k}}
$$

Nilai skor yang telah dinormalkan berada antara 0 hingga 1 dan prosedur ini membolehkan pembentukan suatu indeks agregat sebagai ukuran kepada indikator modal sosial. Dalam kajian ini setiap indikator modal sosial diandaikan mempunyai kepentingan yang sama. Justeru, ketiga-tiga indikator ini diberikan wajaran yang sama. Sehubungan itu, indeks modal sosial bagi setiap individu $i$ boleh dihitung dengan menggunakan persamaan berikut:

$$
I M S_{i}=\frac{1}{3} \sum_{j=1}^{m} I_{i j}
$$

dengan $\mathrm{IMS}_{i}$ mewakili indeks modal sosial ketua isi rumah ke $i, I_{i j}$ adalah indeks indikator ke- $j$ yang diperoleh melalui Persamaan (1), manakala $m$ adalah bilangan indikator. Indeks ini akan berada antara nilai 0 hingga 1 . Nilai indeks yang menghampiri 1 menggambarkan kedudukan modal sosial yang tinggi, sebaliknya nilai yang menghampiri 0 menunjukkan kedudukan modal sosial yang lemah. 


\section{Model Penentu Indeks Modal Sosial}

Model regresi dibentuk untuk mengenal pasti faktor penentu indeks modal sosial. Pemboleh ubah bersandar adalah indeks modal sosial dan pemboleh ubah bebas adalah lokasi, saiz ahli rumah, jantina, status perkahwinan, tahap kesihatan, kekerapan berpersatuan, umur, negeri, dan tahap pendidikan responden. Empat negeri yang digunakan sebagai dami, iaitu negeri Selangor, Wilayah Persekutuan Kuala Lumpur, Kedah dan Johor, manakala Terengganu dijadikan sebagai pemboleh ubah kawalan. Analisis dalam artikel ini menggunakan dua pengukuran pencapaian pendidikan, iaitu pertama, menggunakan dami tahap pendidikan sekunder dan tertiari, manakala tahap pendidikan rendah dijadikan pemboleh ubah kawalan, dan kedua, menggunakan bilangan tahun persekolahan responden. Kedua-dua ukuran ini penting diuji kerana ia memberi impak yang berbeza. Penggunaan tahap pendidikan membolehkan kita membandingkan kesannya dengan tahap pendidikan yang lain terhadap modal sosial, manakala tahun bersekolah pula mengukur impak pendidikan secara purata terhadap modal sosial. Oleh itu terdapat dua model regresi yang dianggarkan seperti berikut:

$$
\begin{aligned}
& I M S_{i}=\beta_{0}+\beta_{1} J A N_{i}+\beta_{2} U_{M U U R}+\beta_{3} \text { PERK }_{i}+\beta_{4} \text { SAIZ }_{i}+\beta_{5} \text { KES }_{i}+\beta_{6} L O K_{i}+ \\
& \beta_{7} S E L_{i}+\beta_{8} K U L_{i}+\beta_{9} K E D_{i}+\beta_{10} J O H_{i}+\beta_{11} M E N_{i}+\beta_{12} T I N G_{i}+\beta_{13} S T A T_{i}+ \\
& \beta_{14} P E N D_{i}+\mu_{1 i} \\
& I M S_{i}=\alpha_{0}+\alpha_{1} J A N_{i}+\alpha_{2} U_{M U U}+\alpha_{3} \text { PERK }_{i}+\alpha_{4} S A I Z_{i}+\alpha_{5} \text { KES }_{i}+\alpha_{6} L O K_{i}+ \\
& \alpha_{7} S E L_{i}+\alpha_{8} K U L_{i}+\alpha_{9} K E D_{i}+\alpha_{10} J O H_{i}+\alpha_{11} T B S_{i}+\alpha_{12} S T A T_{i}+\alpha_{13} P E N D_{i}+\mu_{2 i}
\end{aligned}
$$

dengan IMS adalah indeks modal sosial dalam nilai peratus, JAN adalah pemboleh ubah dami jantina dengan perempuan $=1$, lelaki $=0$; $U M U R$ adalah umur ketua isi rumah; PERK adalah taraf perkahwinan dengan bujang=1, berkahwin=0; SAIZ adalah bilangan ahli isi rumah; KES adalah pemboleh ubah dami taraf kesihatan dengan sihat $=1$, kurang sihat $=0 ; L O K$ adalah pemboleh ubah dami lokasi dengan bandar=1, lain=0; $S E L$ adalah pemboleh ubah dami negeri Selangor=1, lain=0; KUL adalah pemboleh ubah dami Wilayah Persekutuan Kuala Lumpur=1, lain=0; $K E D$ adalah pemboleh ubah negeri Kedah=1, lain=0; $J O H$ adalah pemboleh ubah dami Johor=1, lain=0; $M E N$ adalah pemboleh ubah dami pencapaian pendidikan menengah $=1$, lain $=0$; dan $T I N G$ adalah pemboleh ubah dami tahap pencapaian pendidikan tinggi=1,lain=0; TBS adalah tahun bersekolah; STAT adalah status pekerjaan dengan sepenuh masa $=1$, separuh masa $=0 ; P E N D$ adalah tingkat pendapatan isi rumah, $i$ adalah individu ke- $i$ dan $\mu$ adalah ralat.

Untuk melihat sama ada wujud masalah multikolineariti atau korelasi antara pemboleh ubah bebas, ujian Variance Inflation Factor (VIF) dilakukan. 
VIF mengukur berapa besar varians bagi pekali yang dianggarkan akan meningkat. Sekiranya wujud masalah multikolineariti, maka koefisien yang dianggarkan akan menjadi tidak stabil dan sukar untuk diinterpretasikan. Sekiranya nilai VIF melebihi 10, maka wujud masalah multikolineariti.

\section{DAPATAN}

\section{Profil Responden}

Jadual 1 menunjukkan profil responden kajian ini. Sebanyak 722 atau 29.6\% daripada jumlah responden adalah wanita. Didapati $25 \%$ daripada responden berumur dalam lingkungan 41 hingga 50 tahun, $24.9 \%$ berumur dalam lingkungan 31 hingga 40 tahun dan $24.3 \%$ berumur dalam lingkungan 20 hingga 31 tahun. Sementara 38 orang atau $1.6 \%$ responden adalah berumur 20 tahun dan ke bawah dan 197 orang atau 1.8\% daripada mereka adalah berumur 61 tahun dan ke atas. Sebanyak $81.8 \%$ responden sudah berkahwin. Tahap kesihatan responden adalah baik dengan 2,142 atau $87.7 \%$ responden berada pada tahap ini. Sebanyak 1,407 orang atau $57.6 \%$ responden tinggal di kawasan bandar, manakala $42.4 \%$ responden lain tinggal di kawasan luar bandar. Responden di Johor mencatatkan peratusan tertinggi diikuti oleh Terengganu, Selangor, Kedah dan Wilayah Persekutuan Kuala Lumpur.

Sebanyak 367 orang atau $15 \%$ responden mempunyai tahap pendidikan setakat darjah enam atau Ujian Penilaian Sekolah Rendah (UPSR). Sebanyak 44 orang atau $1.8 \%$ responden mempunyai ijazah di peringkat sarjana dan hanya 3 orang responden yang mempunyai pendidikan peringkat $\mathrm{PhD}$. Didapati 1,694 atau $69.3 \%$ responden bekerja sepenuh masa, manakala $30.7 \%$ lagi bekerja separuh masa. Kebanyakan responden mempunyai pendapatan bulanan sebanyak RM3,000 dan ke bawah, iaitu merangkumi 79\%, manakala $18.3 \%$ mempunyai pendapatan RM3,001 hingga RM6,000. Hanya 2.6\% responden mempunyai pendapatan sebanyak RM6,001 dan ke atas. 
Jadual 1: Profil responden

\begin{tabular}{|c|c|c|}
\hline & Bilangan & Peratus $(\%)$ \\
\hline \multicolumn{3}{|l|}{ Jantina } \\
\hline Lelaki & 1,721 & 70.4 \\
\hline Perempuan & 722 & 29.6 \\
\hline \multicolumn{3}{|l|}{ Umur } \\
\hline 20 tahun dan ke bawah & 38 & 1.6 \\
\hline $21-30$ tahun & 594 & 24.3 \\
\hline $31-40$ tahun & 609 & 24.9 \\
\hline $41-50$ tahun & 610 & 25.0 \\
\hline $51-60$ tahun & 395 & 16.2 \\
\hline 61 tahun dan ke atas & 197 & 8.1 \\
\hline \multicolumn{3}{|l|}{ Status perkahwinan } \\
\hline Bujang & 444 & 18.2 \\
\hline Sudah berkahwin & 1,999 & 81.8 \\
\hline \multicolumn{3}{|l|}{ Tahap kesihatan } \\
\hline Sihat & 2,142 & 87.7 \\
\hline Kurang sihat & 301 & 12.3 \\
\hline \multicolumn{3}{|l|}{ Lokasi } \\
\hline Bandar & 1,407 & 57.6 \\
\hline Luar bandar & 1,036 & 42.4 \\
\hline \multicolumn{3}{|l|}{ Negeri } \\
\hline Selangor & 527 & 21.6 \\
\hline Johor & 626 & 25.6 \\
\hline Kedah & 459 & 18.8 \\
\hline Terengganu & 541 & 22.1 \\
\hline Wilayah Persekutuan Kuala Lumpur & 290 & 11.9 \\
\hline \multicolumn{3}{|l|}{ Tahun persekolahan } \\
\hline 6 tahun (UPSR) & 367 & 15.0 \\
\hline 9 tahun (PMR) & 274 & 11.2 \\
\hline 13 tahun (SPM/STPM) & 123 & 5.0 \\
\hline 12 tahun $($ Sijil) & 973 & 39.8 \\
\hline 14 tahun (Diploma) & 333 & 13.6 \\
\hline 15 tahun (Sarjana muda) & 326 & 13.3 \\
\hline 17 tahun (Sarjana) & 44 & 1.8 \\
\hline 20 tahun $(\mathrm{PhD})$ & 3 & 0.1 \\
\hline \multicolumn{3}{|l|}{ Status pekerjaan } \\
\hline Bekerja sepenuh masa & 1,694 & 69.3 \\
\hline Separuh masa & 749 & 30.7 \\
\hline \multicolumn{3}{|l|}{ Pendapatan bulanan } \\
\hline RM3,000 dan ke bawah & 1,931 & 79.0 \\
\hline RM3,001-RM6000 & 448 & 18.3 \\
\hline RM6,001-RM9000 & 41 & 1.7 \\
\hline RM9,000 dan ke atas & 23 & 0.9 \\
\hline
\end{tabular}

Sumber: Kerja lapangan (2012). 


\section{Analisis Statistik Deskriptif}

Jadual 2 menunjukkan statistik deskriptif bagi kesemua pemboleh ubah yang digunakan dalam model regresi. Tujuan analisis ini dilakukan bagi melihat sisihan piawai data dan nilai puratanya. Namun bagi pemboleh ubah dami, nilai puratanya adalah menyamai peratus taburan data seperti dalam Jadual 1 apabila didarabkan dengan seratus. Nilai sisihan piawai bagi kebanyakan pemboleh ubah adalah kecil dan menghampiri nilai purata kecuali umur, saiz isi rumah dan tahun pendidikan responden. Hal ini menunjukkan taburan data bagi setiap pemboleh ubah adalah tidak jauh berbeza dan tertumpu kepada nilai purata. Namun perbezaan umur, saiz isi rumah dan tahun pendidikan responden agak pelbagai dan jauh daripada nilai purata. Secara puratanya umur responden adalah 41 tahun dan saiz isi rumah agak kecil, iaitu hanya 1.455 orang. Purata tahun bersekolah responden adalah selama 11.93 tahun. Ukuran tahap pendidikan mengikut tahap pula menunjukkan $56.1 \%$ mempunyai pendidikan peringkat menengah, $28.9 \%$ mempunyai pendidikan peringkat tertiari dan selebihnya mempunyai pendidikan peringkat rendah. Purata pendapatan bulanan responden adalah sebanyak RM2,250.60.

Jadual 2: Statistik deskriptif pemboleh ubah

\begin{tabular}{lcc}
\hline Pemboleh ubah & Purata & Sisihan piawai \\
\hline Umur & 41.63 & 13.223 \\
Status perkahwinan & 0.182 & 0.3857 \\
Saiz isi rumah & 1.455 & 0.7571 \\
Tahap kesihatan & 0.877 & 0.3582 \\
Lokasi & 0.576 & 0.4943 \\
Negeri & & \\
$\quad$ Selangor & 0.216 & 0.4114 \\
$\quad$ Kedah & 0.188 & 0.3907 \\
$\quad$ Wilayah Persekutuan Kuala Lumpur & 0.119 & 0.3235 \\
$\quad$ Johor & 0.256 & 0.4366 \\
Tahun pendidikan & 11.93 & 3.015 \\
Tahap pendidikan & & \\
$\quad$ Sekunder & 0.561 & 0.1222 \\
$\quad$ Tertiari & 0.289 & 0.1155 \\
Status pekerjaan & 0.693 & 0.4612 \\
Pendapatan bulanan (RM) & $2,250.599$ & $1,775.324$ \\
\hline
\end{tabular}

Nota: Pemboleh ubah dami adalah Jantina: perempuan=1, lelaki=0; Status perkahwinan: berkahwin=1, tidak berkahwin=0; Tahap kesihatan: sihat=1, tidak sihat=0; Lokasi: bandar=1, luar bandar=0; Negeri: Selangor $=1$, Kedah=1, Kuala Lumpur=1, Johor=1, Terengganu=0; Tahap pendidikan: menengah=1, tertiari $=1$, rendah $=0$; Status pekerjaan: sepenuh masa $=1$, separuh masa $=0$

Nilai purata bagi pemboleh ubah dami perlu didarabkan dengan 100 bagi mendapatkan peratus setiap pemboleh ubah dalam data. Peratus ini menyamai peratusan dalam Jadual 1.

Sumber: Kerja lapangan (2012). 


\section{Indeks Modal Sosial}

Jadual 3 menunjukkan indeks modal sosial mengikut julat yang dipilih. Didapati lebih daripada satu pertiga responden (36.9\%) mempunyai indeks modal sosial pada tahap tinggi, iaitu antara $0.71-1.00$, manakala $36 \%$ responden yang mempunyai indeks modal sosial pada tahap sederhana, iaitu antara 0.51-0.70. Namun $27.1 \%$ responden mempunyai indeks modal sosial pada tahap rendah, iaitu 0.50 ke bawah. Dapatan ini menunjukkan lebih $70 \%$ ketua isi rumah dalam kajian ini sudah berada pada tahap modal sosial yang agak memuaskan, iaitu pada tahap tahap sederhana dan tinggi. Walau bagaimanapun bagi isi rumah yang berada pada indeks modal sosial yang rendah amat perlu diberi perhatian kerana berkait dengan jaringan, kebolehpercayaan dan norma hidup yang rendah yang menjadi masalah bagi negara mencapai status negara maju.

Jadual 3: Taburan indeks modal sosial responden

\begin{tabular}{lll}
\hline Indeks Modal Sosial & Kekerapan & Peratus \\
\hline$<=0.10$ & 17 & 0.7 \\
$0.11-0.20$ & 75 & 3.1 \\
$0.21-0.3$ & 106 & 4.3 \\
$0.31-0.40$ & 146 & 6.0 \\
$0.41-0.50$ & 319 & 13.0 \\
$0.51-0.60$ & 388 & 15.9 \\
$0.61-0.70$ & 492 & 20.1 \\
$0.71-0.80$ & 512 & 21.0 \\
$0.81-0.90$ & 307 & 12.6 \\
$0.91-100$ & 81 & 3.3 \\
\hline
\end{tabular}

Nota: Indeks modal sosial dihitung dengan menggunakan formula (3).

Perbezaan indeks modal sosial mengikut negeri boleh dilihat melalui Jadual 4. Didapati negeri Johor mempunyai peratusan responden yang tinggi pada tahap indeks modal sosial yang rendah, iaitu dalam lingkungan 0.5 ke bawah yang merangkumi $63.9 \%$ responden. Namun peratusan responden yang berada pada tahap ini di Selangor, Wilayah Persekutuan Kuala Lumpur dan Kedah agak rendah, iaitu merangkumi sekitar 10\%. Sebaliknya, di Selangor dan Wilayah Persekutuan Kuala Lumpur, masing-masing sebanyak 55.4\% dan 66.8\% responden berada pada tahap indeks modal sosial yang tinggi, iaitu 0.71 ke atas. Peratusan responden di Kedah, Terengganu dan Johor yang berada pada tahap indeks modal sosial yang tinggi ini adalah lebih rendah, iaitu masing-masing $50 \%, 29.9 \%$ dan $3.2 \%$. Taburan responden yang berada pada tahap indeks modal sosial sederhana bagi kelima-lima negeri ini agak seragam, iaitu dalam lingkungan 30\%. Dapatan ini memberi implikasi bahawa penduduk di negeri- 
negeri yang lebih maju memiliki tahap modal sosial yang tinggi kecuali negeri Johor kesan daripada pemilihan sampelnya lebih kepada penduduk luar bandar.

Dapatan ini juga menggambarkan ketidakseimbangan dalam pembangunan ekonomi negara ini telah membawa kepada kekurangan kemudahan jaringan, rendahnya tahap kebolehpercayaan dan norma hidup kesan daripada tahap pendidikan yang lebih rendah bagi negeri-negeri yang kurang membangun. Hal ini selanjutnya menyebabkan tahap modal sosial mereka lebih rendah dibandingkan dengan negeri-negeri yang lebih membangun. Masalah ini perlu ditangani agar pembangunan yang akan berlaku selanjutnya dapat memberi manfaat yang seimbang kepada seluruh rakyat tanpa mengira negeri.

Jadual 4: Taburan indeks modal sosial mengikut negeri

\begin{tabular}{lcccccccccc}
\hline $\begin{array}{l}\text { Indeks } \\
\text { modal } \\
\text { sosial }\end{array}$ & \multicolumn{2}{c}{ Selangor } & \multicolumn{2}{c}{ Johor } & \multicolumn{2}{c}{ Kedah } & \multicolumn{2}{c}{ Terengganu } & \multicolumn{2}{c}{$\begin{array}{c}\text { Wilayah Persekutuan } \\
\text { Kuala Lumpur }\end{array}$} \\
\cline { 2 - 12 } & Bil. & $\%$ & Bil. & $\%$ & Bil. & $\%$ & Bil. & $\%$ & Bil. & $\%$ \\
\hline$<=0.10$ & 0 & 0.0 & 14 & 2.2 & 0 & 0.0 & 3 & 0.5 & 0 & 0.0 \\
$0.11-0.20$ & 1 & 0.2 & 64 & 10.2 & 1 & 0.2 & 9 & 1.7 & 0 & 0.0 \\
$0.21-0.3$ & 0 & 0.0 & 77 & 12.3 & 0 & 0.0 & 29 & 5.4 & 0 & 0.0 \\
$0.31-0.40$ & 1 & 0.2 & 100 & 16.0 & 14 & 3.1 & 29 & 5.4 & 2 & 0.7 \\
$0.41-0.50$ & 26 & 4.9 & 145 & 23.2 & 34 & 7.4 & 85 & 15.7 & 29 & 10.0 \\
$0.51-0.60$ & 61 & 11.6 & 136 & 21.7 & 64 & 13.9 & 93 & 17.2 & 34 & 11.7 \\
$0.61-0.70$ & 146 & 27.7 & 70 & 11.2 & 114 & 24.8 & 131 & 24.2 & 31 & 10.7 \\
$0.71-0.80$ & 162 & 30.7 & 13 & 2.1 & 134 & 29.2 & 113 & 20.9 & 90 & 31.0 \\
$0.81-0.90$ & 98 & 18.6 & 7 & 1.1 & 81 & 17.6 & 45 & 8.3 & 76 & 26.2 \\
$0.91-100$ & 32 & 6.1 & 0 & 0.0 & 17 & 3.7 & 4 & 0.7 & 28 & 9.6 \\
\hline
\end{tabular}

Nota: Indeks modal sosial dihitung dengan menggunakan formula (3).

\section{Keputusan Penganggaran Model}

Jadual 5 menunjukkan keputusan penganggaran model indeks modal sosial. Keputusan bagi ujian multikolineariti menunjukkan tidak wujud masalah ini kerana kesemua pemboleh ubah mempunyai nilai VIF kurang daripada 10. Kebanyakan nilai VIF adalah kurang daripada 2 dan hanya pemboleh ubah tahap persekolahan mempunyai nilai VIF yang agak tinggi tetapi masih rendah daripada 10. Bagi model pertama, nilai $R$ squared $\left(\mathrm{R}^{2}\right)$ adalah 0.381 yang menunjukkan sebanyak $38.1 \%$ variasi dalam pemboleh ubah bersandar dapat diterangkan oleh pemboleh ubah bebas. 
Jadual 5: Keputusan penganggaran model regresi

\begin{tabular}{|c|c|c|}
\hline Pemboleh ubah & Model 1 & Model 2 \\
\hline Konstan & $\begin{array}{l}55.234^{* * *} \\
(6.782)\end{array}$ & $\begin{array}{l}52.847^{* * *} \\
(14.369)\end{array}$ \\
\hline Jantina & $\begin{array}{l}0.946 \\
(1.246)\end{array}$ & $\begin{array}{l}1.125 \\
(1.488)\end{array}$ \\
\hline Umur & $\begin{array}{l}0.029 \\
(0.877)\end{array}$ & $\begin{array}{l}0.028 \\
(0.801)\end{array}$ \\
\hline Status perkahwinan & $\begin{array}{l}1.874^{*} \\
(1.855)\end{array}$ & $\begin{array}{l}1.879^{*} \\
(1.859)\end{array}$ \\
\hline Saiz isi rumah & $\begin{array}{l}-0.280 \\
(-0.519)\end{array}$ & $\begin{array}{l}-0.366 \\
(-0.677)\end{array}$ \\
\hline Tahap kesihatan & $\begin{array}{l}1.133 \\
(1.176)\end{array}$ & $\begin{array}{l}1.178 \\
(1.220)\end{array}$ \\
\hline Lokasi & $\begin{array}{l}1.355^{* *} \\
(1.989)\end{array}$ & $\begin{array}{l}1.426^{* *} \\
(2.073)\end{array}$ \\
\hline Selangor & $\begin{array}{l}12.251^{* * *} \\
(12.872)\end{array}$ & $\begin{array}{l}12.232^{* * *} \\
(12.832)\end{array}$ \\
\hline Johor & $\begin{array}{l}-16.878^{\text {**** }} \\
(-18.660)\end{array}$ & $\begin{array}{l}-16.955^{* * *} \\
(-18.739)\end{array}$ \\
\hline Kedah & $\begin{array}{l}9.980^{* * * *} \\
(10.115)\end{array}$ & $\begin{array}{l}10.002^{* * * *} \\
(10.132)\end{array}$ \\
\hline Wilayah Persekutuan Kuala Lumpur & $\begin{array}{l}13.244^{* * *} \\
(11.070)\end{array}$ & $\begin{array}{l}13.124^{* * *} \\
(10.963)\end{array}$ \\
\hline Tahap pendidikan sekunder & $\begin{array}{l}-2.750 \\
(-0.358)\end{array}$ & \\
\hline Tahap pendidikan tertiari & $\begin{array}{l}2.889 \\
(0.355)\end{array}$ & \\
\hline Tahun bersekolah & & $\begin{array}{l}-0.016 \\
(-0.130)\end{array}$ \\
\hline Status pekerjaan & $\begin{array}{l}0.438 \\
(0.576)\end{array}$ & $\begin{array}{l}0.494 \\
(0.634)\end{array}$ \\
\hline Pendapatan & $\begin{array}{l}3.522^{*} \\
(1.793)\end{array}$ & $\begin{array}{l}3.449^{*} \\
(1.735)\end{array}$ \\
\hline $\mathrm{R}^{2}$ & 0.381 & 0.380 \\
\hline Adj. $R^{2}$ & 0.378 & 0.377 \\
\hline $\mathrm{N}$ & 2443 & 2443 \\
\hline $\begin{array}{c}{ }^{* * *} \quad \text { signifikan pada aras keertia } \\
\text { N }^{* *} \quad \text { signifikan pada aras keertia } \\
{ }^{*} \quad \text { signifikan pada aras keerti } \\
\text { Angka dalam kurungan adalah }\end{array}$ & & \\
\hline
\end{tabular}

Bagi Model 1, daripada 14 pemboleh ubah bebas yang dimasukkan ke dalam model anggaran, hanya tujuh pemboleh ubah bebas yang menunjukkan keputusan yang signifikan iaitu status perkahwinan, dami lokasi, kesemua dami 
pekali negeri, dan tingkat pendapatan isi rumah. Dapatan kajian menunjukkan purata indeks modal sosial bagi responden yang masih bujang adalah $1.874 \%$ lebih tinggi daripada responden yang sudah berkahwin dan ia signifikan pada aras keertian $10 \%$. Dapatan ia bertepatan dengan hujah yang diutarakan oleh Bolin et al. (2003). Mereka menyatakan pasangan yang sudah berkahwin dijangkakan mempunyai tingkat modal sosial yang lebih rendah berbanding dengan individu yang belum berkahwin kerana pasangan yang berkahwin akan menumpukan lebih banyak masa kepada keluarga dan akan mengurangkan keperluan bersosial di luar rumah. Sementara menurut Li, Savage dan Pickles (2003), modal sosial bagi pasangan yang sudah berkahwin adalah lebih ke arah tanggungjawab kejiranan dan penglibatan sivik berbanding dengan jaringan sosial. Skop penglibatan yang lebih terhad ini membawa kepada tingkat modal sosial mereka lebih rendah dibandingkan dengan pasangan yang belum berkahwin.

Hasil kajian juga menunjukkan responden yang tinggal di bandar secara puratanya mempunyai indeks modal sosial yang lebih tinggi sebanyak $1.355 \%$ berbanding responden yang tinggal di kawasan luar bandar. Nilai ini adalah signifikan pada aras keertian 5\%. Keputusan kajian ini disokong oleh kajian Katungi, Machethe dan Smale (2007), yang turut memperoleh hubungan positif modal sosial dengan kawasan bandar yang mempunyai kemudahan yang pesat berbanding dengan kawasan luar bandar yang mempunyai kekangan dari segi kemudahan.

Bagi negeri Selangor, nilai purata indeks modal sosial adalah $12.251 \%$ lebih tinggi daripada Terengganu dan ia signifikan pada aras keertian $1 \%$. Sementara nilai purata indeks modal sosial bagi Wilayah Persekutuan Kuala Lumpur adalah $13.244 \%$ lebih tinggi daripada Terengganu. Kedua-dua negeri ini dikategorikan sebagai negeri yang sangat maju di Malaysia. Bagi negeri Johor pula, nilai purata indeks modal sosialnya $16.878 \%$ lebih rendah daripada Terengganu dan signifikan pada aras keertian $1 \%$. Nilai purata yang lebih rendah ini kemungkinan disebabkan oleh lokasi kutipan data di negeri Johor di mana kebanyakannya dilakukan di kawasan luar bandar yang mempunyai indeks modal sosial yang lebih rendah berbanding kawasan luar bandar. Indeks modal sosial bagi negeri Kedah adalah $9.98 \%$ lebih tinggi berbanding di Terengganu dan ia signifikan pada aras keertian $1 \%$.

Dapatan ini menggambarkan, walaupun Terengganu dan Kedah samasama dikategorikan sebagai negeri kurang maju di Malaysia, tahap modal sosial rakyatnya berbeza. Ia mungkin disebabkan oleh kemudahan asas yang lebih baik di Kedah yang membolehkan mereka menjalankan aktiviti sosial dengan lebih teratur. Bagi negeri maju seperi Selangor dan Wilayah Persekutuan Kuala Lumpur, keputusan ini jelas menunjukkan tahap pembangunan ekonomi memainkan peranan yang amat penting dalam meningkatkan tahap modal sosial rakyat sesebuah negeri yang akhirnya menyumbang kepada tahap pembangunan ekonomi yang lebih tinggi. 
Pemboleh ubah lain yang signifikan dalam menentukan indeks modal sosial ialah tingkat pendapatan. Didapati peningkatan satu ringgit dalam tingkat pendapatan akan meningkatkan indeks modal sosial sebanyak $3.522 \%$ dan ia signifikan pada aras keertian $10 \%$. Keputusan ini sama dengan hasil dapatan kajian bagi kajian Christoforou (2005) yang mendapati hubungan antara pendapatan dengan keahlian dalam persatuan yang merupakan salah satu komponen modal sosial adalah positif dan signifikan. Keputusan ini turut disokong oleh kajian Knack dan Keefer (1997) yang mendapati terdapat hubungan yang positif dan signifikan antara tingkat pendapatan dengan dimensidimensi dalam modal sosial. Menurut Knack dan Keefer (1997), individu yang mempunyai pendapatan yang tinggi akan mempunyai tingkat modal sosial yang tinggi. Menurut Katungi, Machethe dan Smale (2007), individu yang kaya lebih banyak melibatkan diri dalam persatuan. Penyertaan dalam sesebuah persatuan memerlukan wang dan masa yang merupakan kekangan bagi individu yang kurang mampu dalam aspek pendapatan.

Berdasarkan kajian ini, hubungan positif antara tingkat pendapatan dengan indeks modal sosial di Malaysia membuktikan bahawa individu yang mempunyai pendapatan yang tinggi akan lebih terdorong untuk melibatkan diri dalam aktiviti berpersatuan kerana faedah positif yang diperolehi daripada sesebuah persatuan yang diikutinya. Sementara individu yang berpendapatan rendah terdorong untuk lebih banyak menghabiskan masa dengan bekerja keras bagi mendapatkan wang harian untuk menampung perbelanjaan harian mereka.

Hasil penganggaran model kedua tidak menunjukkan perbezaan yang besar daripada hasil penganggaran model pertama. Bagi kedua-dua model, pencapaian pendidikan yang diukur melalui tahap pencapaian pendidikan dan tahun bersekolah tidak memberi kesan yang signifikan terhadap indeks modal sosial ketua isi rumah yang dikaji. Dapatan ini menggambarkan komponen modal sosial; jaringan sosial, kepercayaan dan norma hidup tidak dipengaruhi secara signifikan oleh tingkat pendidikan individu. Dapatan ini bertentangan dengan dapatan kajian Knack dan Keefer (1997) yang menemui hubungan positif antara modal sosial dengan tahap pencapaian pendidikan. Percanggahan ini mungkin disebabkan oleh sistem pendidikan di Malaysia yang kurang mampu menerapkan nilai-nilai sahsiah yang boleh meningkatkan modal sosial individu.

\section{PERBINCANGAN DAN KESIMPULAN}

Berdasarkan dapatan kajian ini, indeks modal sosial kebanyakan isi rumah dalam kajian ini berada pada tahap sederhana dan tinggi. Namun, masih ada dalam kalangan mereka yang memiliki indeks modal sosial yang rendah. Analisis mengikut negeri pula menunjukkan terdapat perbezaan yang besar dalam peratus responden yang berada pada pelbagai tahap modal sosial. Didapati negeri-negeri yang lebih maju mempunyai peratus responden yang tinggi dengan tahap modal 
sosial yang tinggi. Keadaan ini boleh menerangkan peranan dua hala yang dimainkan oleh tahap pembangunan ekonomi dan indeks modal sosial. Tahap pembangunan yang tinggi menyebabkan rakyatnya mempunyai indeks modal sosial yang tinggi atau sebaliknya tahap modal sosial yang tinggi akan membawa kepada tahap pembangunan ekonomi yang lebih tinggi pula. Hubungan sebeginilah yang diperlukan negara dalam mencapai status negara maju. Namun kekecualian berlaku di Johor disebabkan taburan responden yang lebih tertumpu kepada kawasan luar bandar kesan daripada kekangan dalam proses mengutip data.

Didapati hanya tujuh daripada pemboleh ubah bebas yang digunakan dalam kajian ini adalah positif dan signifikan dalam menentukan indeks modal sosial. Ia termasuk status perkahwinan, lokasi, dami empat negeri iaitu negeri Selangor, Wilayah Persekutuan Kuala Lumpur, Johor dan Kedah, dan pendapatan isi rumah. Namun pemboleh ubah pendidikan tidak menunjukkan pengaruh yang signifikan. Responden yang masih bujang dan yang tinggal di kawasan bandar mempunyai indeks modal sosial yang lebih tinggi berbanding responden yang sudah berkahwin dan yang tinggal di luar bandar. Ketua isi rumah yang tinggal di negeri Selangor, Kedah dan Wilayah Persekutuan Kuala Lumpur juga mempunyai indeks modal sosial yang lebih tinggi daripada di Terengganu. Namun, indeks modal sosial bagi mereka yang tinggal di Johor adalah lebih rendah daripada Terengganu. Pengaruh pendapatan terhadap indeks modal sosial adalah positif dan signifikan.

Berdasarkan hasil kajian, tingkat pendapatan adalah paling releven dengan implikasi dasar. Individu yang mempunyai pendapatan tinggi akan mempunyai indeks modal sosial yang lebih tinggi. Maka kerajaan seharusnya menyusun lebih banyak strategi yang boleh membantu masyarakat khususnya mereka yang berpendapatan rendah untuk meningkatkan pendapatan mereka sama ada melalui pinjaman modal perniagaan ataupun memberikan mereka peluang untuk belajar dalam kemahiran tertentu. Selain itu, pemboleh ubah dami lokasi menunjukkan responden di kawasan bandar mempunyai indeks modal sosial yang lebih tinggi berbanding kawasan luar bandar. Maka kerajaan harus memainkan peranan dalam memajukan dan membangunkan kawasan luar bandar khususnya dalam aspek pembangunan infrastuktur dan peluang pekerjaan untuk mengurangkan jurang perbezaan sosioekonomi antara kawasan bandar dan luar bandar. Hal ini juga selaras dengan dapatan kajian yang menunjukkan isi rumah yang tinggal di negeri-negeri yang lebih maju mempunyai indeks modal sosial yang lebih tinggi. Dalam konteks ini pembangunan seimbang amatlah diperlukan dengan cara memajukan negeri yang masih terkebelakang melalui penjanaan aktiviti ekonomi dan penjanaan peluang pekerjaan yang lebih lancar.

Kajian ini mempunyai beberapa batasan dan ia boleh diperbaiki untuk kajian yang akan datang. Kajian selanjutnya perlu merangkumi kesemua negeri di Malaysia supaya perbandingan boleh dilakukan dengan lebih luas. Selain itu ia perlu mengambil kira etnik yang berbeza bagi melihat sejauh mana perbezaan 
modal sosial antara etnik dan menjawab persoalan agihan pendapatan antara etnik di Malaysia. Penggunaan sampel yang lebih besar sudah tentu dapat memberi gambaran yang lebih menyeluruh dan menjawab persoalan kajian dengan lebih tepat.

\section{PENGHARGAAN}

Artikel ini merupakan hasil penyelidikan di bawah Geran Universiti Penyelidikan, Universiti Kebangsaan Malaysia, UKM-EP-04-FRGS0013-2006.

\section{RUJUKAN}

Alesina, A. and E. La Ferrara. 2000. Participation in heterogeneous communities. Quarterly Journal of Economics 115(3): 847-904. http://dx.doi.org/10.1162/003355300554935.

Bolin, K., B. Lindgren, M. Lindström and P. Nystedt. 2003. Investments in social capital - implications of social interactions for the production of health. Social Science and Medicine 56: 2379-2390. http://dx.doi.org/ 10.1016/S0277-9536(02)002423.

Bjørnskov, C. and G. T. Svendsen. 2003. Measuring social capital: Is there a single underlying explanation? Working paper 3-5, Department of Economics, Aarhus School of Business, University of Aarhus.

Boxman, Ed A. W., P. M. De Graaf and H. D. Flap. 1991. The impact of social and human capital on the income attainment of Dutch managers. Social Networks 13: 51-73. http://dx.doi.org/10.1016/0378-8733(91)90013-J.

Christoforou, A. 2005. On the determinants of social capital in Greece compared to countries of the European Union. Working Paper 68, Fondazione EniEnrico Mattei (FEEM).

Coleman, J. S. 1990. Foundations of social theory. Cambridge: The Belknap Press of Harvard University Press.

1988. Social capital in the creation of human capital. American Journal of Sociology 94(supplement): S95-S120. http://dx.doi.org/10.1086/ 228943.

Fidrmuc, J. and K. Gerxhani. 2004. Formation of social capital in Eastern Europe: Explaining gap developed countries. Discussion Paper 5068, Centre for Economic Policy Research (CEPR).

Fukuyama, F. 1999. Social capital and civil society. Paper presented at the IMF Conference on Second Generation Reforms, IMF Institute and Foreign Affairs Depatment, IMF Headquarters, Washington, DC. 8-9 November.

Glaeser, L. E., D. Laibson and B. Sacerdote. 2002. The economic approach to social capital. The Economic Journal 112: F437-F458. http://dx.doi.org/10.1111/14680297.00078 .

Grootaert, C. 2004. Measuring social capital. The World Bank Working Paper No. 18. Washington DC: The World Bank. 
Hair, J. F. 2010. Multivariate data analysis: A global perspective. 7th ed. Upper Saddle River: Prentice Hall.

Hermann D. and P. Mahieu. 2012. Community-based health insurance and social capital: A review. Health Economics Review 2(1): 1-5.

Israel, G. D. 1992. Sampling the evidence of extension program impact. Program Evaluation and Organizational Development, The Institute of Food and Agricultural Sciences (IFAS), University of Florida. PEOD-5. October.

Jabatan Kebajikan Masyarakat. 2003. Dasar sosial negara. Kuala Lumpur: Jabatan Kebajikan Masyarakat.

Jabatan Perdana Menteri. 2014. Economic transformation plan annual report. Kuala Lumpur: Jabatan Perdana Menteri.

Kaasa, A. and E. Parts. 2008. Individual-level determinants of social capital in Europe: Differences between country groups. Acta Sociologica 51(2):145-168. http://dx.doi.org/10.1177/0001699308090040.

Katungi, E., C. Machethe and M. Smale. 2007. Determinants of social capital formation in rural Uganda: Implications for group-based agricultural extension approaches. The African Journal of Agricultural and Resource Economics 1(2):167-190.

Knack, S. 2002. Social capital, growth and poverty: A survey of cross-country evidence. In The role of social capital in development. An empirical assesment, eds. Grootaert. C. and T. Van Bastelaer. Cambridge: Cambridge University Press. http://dx.doi.org/10.1017/cbo9780511492600.004.

Knack, S. and P. Keefer. 1997. Does social capital have an economic payoff? A crosscountry investigation. Quarterly Journal of Economics 112(4):1251-1288. http://dx.doi.org/10.1162/003355300555475

Krishna, A. and N. Uphoff. 1999. Mapping and measuring social capital: A conceptual and empirical study of collective action for conserving and developing watersheds in Rajasthan, India. Working Paper 13, Social capital initiative. Washington DC: The World Bank.

Li, Y., M. Savage and A. Pickles. 2003. Social capital and social trust in Britain. European Sociological Review 21(2):109-123. http://dx.doi.org/10. 1093/esr/jci007

Maluccio, A. J., L. Haddad and J. May. 2003. Social capital and gender in South Africa, 1993-1998. In Household decisions, gender and development: A synthesis of recent research, ed. A. R. Quisumbing, 145-152. Washington, DC: International Food Policy Research Institute.

Narayan, D. and F. C. Michael. 2001. A dimensional approach to measuring social capital: Development and validation of a social capital inventory. Current Sociology 49: 59-102. http://dx.doi.org/10.1177/0011392101049002006.

Noorasiah Sulaiman and Mohd. Nasir Mohd Saukani. 2007. Modal sosial dalam mempertingkat daya saing firma perusahaan kecil dan sederhana. International Journal of Management Studies 14(2): 93-111.

Putnam, R. D. 2001. Social capital: Measurement and consequences. Canadian Journal of Policy Research 2:41-51. . 1993. Making democracy work: Civic traditions in modern Italy. Princeton: Princeton University Press. 
Rahmah Ismail, Ishak Yussof, Zulkifly Osman, Abd Hair Awang dan Liew Che Siang. 2009. Daya saing pekerja dalam sektor perkhidmatan swasta di Malaysia. Laporan akhir penyelidikan, Projek Sciencefund. Ministry of Science, Technology abd Innovation (MOSTI), kod 06-01-02-SF0099.

Robinson, D. 1999. Social capital in action. IPS Policy Newsletter, No. 57/May. Institute of Policy Studies (IPS), Victoria University of Wellington.

Roslan Abdul-Hakim, Russayani Ismail and Nor Azam Abdul Razak. 2010. Does social capital reduce poverty? A case study of rural households in Terengganu, Malaysia. European Journal of Social Sciences 14(4): 556-566.

Seligman, A. 1997. The problem of trust. Princeton: Princeton University Press. Quoted in Siisiäinen, 2000.

Siisiäinen, M. 2000. Two concepts of social capital: Bourdieu vs. Putnam. Paper presented at ISTR Fourth International Conference "The Third Sector: For What and for Whom?" Trinity College, Dublin, Ireland, 5-8, July. http://ahsc5p09socialcapital.wikispaces.com/file/history/Siisianen+\%282000\%2 9+Two+concepts+of+social+capital.pdf (accessed 9 April 2015).

Unit Perancang Ekonomi. 2006. Indeks kemajuan komposit. Kuala Lumpur: Percetakan Nasional.

Whiteley, P. F. 2000. Economic growth and social capital. Political Studies 48(3): 443466. 